\title{
MTHFR and MDR1 Gene Polymorphisms in Yakut Patients with Non-Syndromic Orofacial Clefts
}

\author{
Aleksandra T. Diakonova ${ }^{1}$; Nadezhda I. Pavlova, $\mathrm{PhD}^{1 *}$; Vladislav A. Alekseev ${ }^{1}$; \\ Lyubov S. Mironova ${ }^{2,3}$, PGS; Khariton A. Kurtanov ${ }^{4}, \mathrm{PhD}$; Vladimir V. Dodokhov \\ Innokenty D. Ushnitsky ${ }^{2}, \mathrm{PhD}, \mathrm{ScD}$ \\ ${ }^{1}$ Yakut Science Center of Complex Medical Problems \\ ${ }^{2}$ The North-Eastern Federal University named after M.K. Ammosov \\ ${ }^{3}$ Republic Hospital No. 1 - National Center of Medicine \\ ${ }^{4}$ Institute for Biological Problems of Cryolithozone of SB of RAS \\ ${ }^{5}$ Arctic State Agrotechnological University \\ Yakutsk, the Republic of Sakha (Yakutia), Russia
}

\begin{abstract}
Background: Non-syndromic malformations of the face, jaws, and teeth are quite frequent, and, often, serious diseases, representing one of the complex problems of maxillofacial surgery and surgical dentistry. The aim of our study was to investigate the relationship between the MDR1 and MTHFR gene polymorphisms and non-syndromic cleft lip with or without cleft palate (NSCL/P) in the Yakut population in the Republic of Sakha (Yakutia).

Methods and Results: The sample of examined persons consisted of 60 children with NSCL/P. The NSCL/P group was divided into the CLP (cleft lip with cleft palate) subgroup ( $\mathrm{n}=31$ ), CLO (cleft lip only) subgroup ( $\mathrm{n}=14$ ), and CPO (cleft palate only) subgroup $(\mathrm{n}=15)$. The comparison group (control) included 174 healthy volunteers who did not have relatives with OFCs. The study of the MDR1 rs1045642 SNP and the MTHFR rs1801133 SNP was performed by PCR and RFLP analysis.

Analysis of the frequency distribution of alleles and genotypes depending on the severity of clefts showed that the carriage of the TT homozygous genotype of the MDR1 rs $1045642 \mathrm{SNP}$ was associated with significant risk for the development of NSCL/P $(\mathrm{OR}=2.52,95 \% \mathrm{CI}: 1.19-5.32, P=0.02)$. Analysis of the recessive model (TT vs CC + TC) also found a significant risk of NSCL $/ \mathrm{P}$ with the TT genotype carriage (OR=2.20, 95\% CI: 1.06-4.57, $P=0.04)$. Analysis of the over-dominant model (TC vs TT + CC) showed that the heterozygous TC genotype had a protective effect ( $\mathrm{OR}=0.41 ; 95 \% \mathrm{CI}$ : $0.22-0.77, P=0.01)$ on the development of NSCL/P. Subgroup analysis according to NSCL/P subtypes (CLO, CPO and CLP) showed that the MDR1 rs1045642 SNP was significantly associated with a high risk of CPO in three genetic models: heterozygous [(TT vs TC): OR=5.03; 95\% CI: 1.55 16.32; $P=0.01$ ], recessive [(TT vs $\mathrm{CC}+\mathrm{TC}): \mathrm{OR}=3.96 ; 95 \% \mathrm{CI}: 1.32-11.95 ; P=0.02]$, and over-dominant [(TC vs TT $+\mathrm{CC})$ : $\mathrm{OR}=0.23 ; 95 \%$ CI: $0.08-0.66 ; P=0.01]$.
\end{abstract}

Conclusion: A study of two SNPs in the MDRland MTHFR genes revealed a statistically significant increased risk for NSCL/P in carriers of the TT genotype of the MDRI rs1045642 SNP. (International Journal of Biomedicine. 2021;11(4):576-580.)

Key Words: orofacial cleft $・$ MDR1 gene $・$ MTHFR gene $・$ single nucleotide polymorphism

For citation: Diakonova AT, Pavlova NI, Alekseev VA, Mironova LS, Kurtanov KhA, Dodokhov VV, Ushnitsky ID. MTHFR and MDR1 Gene Polymorphisms in Yakut Patients with Non-Syndromic Orofacial Clefts. International Journal of Biomedicine. 2021;11(4):576-580. doi:10.21103/Article11(4)_OA29

\section{Abbreviations}

CLP, cleft lip with cleft palate; CLO, cleft lip only; CPO, cleft palate only; IRF6, interferon regulatory factor 6; LD, linkage disequilibrium; MTHFR, methylenetetra-hydrofolate reductase; MDR1, multidrug resistance 1; NSCL/P, non-syndromic cleft lip with or without cleft palate; OFC, orofacial cleft; SNP, single nucleotide polymorphism. 


\section{Introduction}

Non-syndromic malformations of the face, jaws, and teeth are quite frequent, and, often, serious diseases, representing one of the complex problems of maxillofacial surgery and surgical dentistry. According to Ushnitsky et al., in the structure of clefts, heredity accounts for $7.55 \pm 2.18 \%$. Moreover, every eighth cleft lip and (or) palate is part of multiple congenital malformations. ${ }^{(1)}$

The organ primordia of the maxillofacial system develop in the first trimester of pregnancy from the first and second branchial arches, as well as the frontal protrusion of the cerebral region. From the branchial arches, tissues of the maxillofacial and submandibular regions are formed, with the exception of the central part of the midface zone, which develops from the frontal protrusion of the cerebral region. The development of the fetal lips ends at about 5-6 weeks, and the palate closes at about 10 weeks of gestation. ${ }^{(2)}$ Disorders of the fusion of the secondary palate can be caused by an already existing cleft in the primary palate or can occur separately with a normally developed primary palate.

To clarify the etiology of congenital facial clefts, it is necessary to study how genetic susceptibility factors interact with environmental factors. In recent years, studies of genetic predisposition in the development of non-syndromic cleft lip with or without cleft palate (NSCL/P) have become widespread. Reliable associations of the MDRI and MTHFR gene variants with an increased risk for NSCL/P have been found in different populations. ${ }^{(3-5)}$

The MTHFR gene, encoding the synthesis of the MTHFR enzyme, is located on chromosome 1p36.3. MTHFR plays a key role in folic acid metabolism. The value of folate in the prevention of neural tube defects (NTDs) is well established ${ }^{(6,7)}$ and recent studies showing hypomethylation of neural tissue in cases of NTD support this observation. ${ }^{(8-11)}$

The rs1801133 SNP (also known as $677 \mathrm{C}>\mathrm{T}$ ) is localized in exon 4 of the MTHFR gene and is formed by the transition from cytosine (C) to thymine (T). The 222nd genetic code of the MTHFR gene changes from GCC to GTC, which leads to the replacement of alanine (Ala) with valine (Val) in the MTHFR polypeptide. Animal studies have shown that reducing the formation of methionine from homocysteine plays a key role in the development of neural tube defects. A number of studies investigated the relationship between the polymorphisms of the MTHFR gene and OFCs, but with mixed results. ${ }^{(3,5,10)}$

Functional SNPs in the MDRI gene can affect the expression and activity of transport proteins located on the apical and basolateral surfaces of syncytiotrophoblast and placental capillary endothelial cells. These proteins are able to remove toxins or drugs from the environment that enter the mother's body, into the mother's bloodstream, and can lead to an altered response of the fetus on xenobiotics and a subsequent increase in the risk of complex genetic disorders or birth defects.(4) Pels et al. suggest that the rs1045642 SNP (also known as $3435 \mathrm{C}>\mathrm{T}$ ) has an adaptive significance, or is linked to other polymorphic sites that have an adaptive significance. $^{(12)}$
The aim of our study was to investigate the relationship between the MDR1 and MTHFR gene polymorphisms and $\mathrm{NSCL} / \mathrm{P}$ in the Yakut population in the Republic of Sakha (Yakutia).

\section{Materials and Methods}

The experimental part of the work on the genotyping of the MDR1 rs1045642 SNP and the MTHFR rs1801133 SNP was carried out in the Department of Molecular Genetics at YSC CMP. For the study, we used DNA samples from the collection of biomaterials of the YSC CMP (Project "The Genome of Yakutia"; No. USE_507512).

The sample of examined persons consisted of 60 children (29 girls and 31 boys) with NSCL/P. The NSCL/P group was divided into the CLP subgroup $(n=31)$, CLO subgroup $(\mathrm{n}=14)$, and CPO subgroup $(\mathrm{n}=15)$. According to indications, a cytogenetic examination was performed to exclude chromosomal pathology in this group of children. The comparison group (control) included 174 healthy volunteers (128 women and 46 men) who did not have relatives with OFCs.

The study was approved by the Ethics Committee of the Yakut Science Center of Complex Medical Problems (YSC CMP). Written informed consent was obtained from each research participant (or the participant's parent/guardian).

Genomic DNA samples were isolated from the peripheral blood leukocytes using a commercial kit for DNA isolation Excell biotech (Yakutsk, Russia). The study of the MDR1 rs1045642 SNP and the MTHFR rs1801133 SNP was performed by PCR and RFLP analysis. Primer sequences, conditions for amplification, restriction pattern, restriction enzymes, and the lengths of the restoration fragments are presented in Table 1 .

Table 1.

The primers and restriction enzymes used for detection of MDRI and MTHFR SNPs using PCR-RFLP method

\begin{tabular}{|c|c|c|c|c|}
\hline $\begin{array}{c}\text { Gene / } \\
\text { RefSNP ID }\end{array}$ & Primers & AT & $\mathrm{RE}$ & RFL \\
\hline \multirow{2}{*}{$\begin{array}{l}\text { MDR1 } \\
\text { rs1045642 }\end{array}$} & $\begin{array}{l}\text { F: 5'-TTGATGGCA } \\
\text { AAGAAATAAAGC-3' }\end{array}$ & \multirow{2}{*}{$54^{\circ} \mathrm{C}$} & \multirow{2}{*}{ DpnI } & \multirow{2}{*}{$\begin{array}{l}\text { CC: } 130,76 \mathrm{bp} \\
\text { CT: } 206,130,76 \mathrm{bp} \\
\text { TT: } 206 \mathrm{bp}\end{array}$} \\
\hline & $\begin{array}{l}\text { R: 5'-CTTACATTA } \\
\text { GGCAGTGACTCG-3' }\end{array}$ & & & \\
\hline \multirow{2}{*}{$\begin{array}{l}\text { MTHFR } \\
\text { rs1801133 }\end{array}$} & $\begin{array}{l}\text { F: 5'-TGGGGTCAG } \\
\text { AAGCATATCAGTCA -3, }\end{array}$ & \multirow{2}{*}{$62^{\circ} \mathrm{C}$} & \multirow{2}{*}{ TaqI } & \multirow{2}{*}{$\begin{array}{l}\text { CC: } 497 \mathrm{bp} \\
\text { TC: } 497,271,226 \mathrm{bp} \\
\text { TT: } 271,226 \mathrm{bp}\end{array}$} \\
\hline & $\begin{array}{l}\text { R: 5'-CTGGGAAGA } \\
\text { ACTCAGCGAAC-3' }\end{array}$ & & & \\
\hline
\end{tabular}

$A T$, annealing temperature; $R E$, restriction enzyme; $R F L$ - restriction fragment length; $b p$, base pair

Genotypes were determined by analyzing the sizes of the resulting fragments by gel electrophoresis on a $4 \%$ agarose gel with ethidium bromide in a standard Tris-acetate buffer at $120 \mathrm{~V}$ for 1 hour. Restriction products were visualized using a UV gel documentation system (Vilber Lourmat, France). 
Statistical analysis was performed using Microsoft Excel 2010. Differences in the allele and genotype distribution between the groups were assessed by $\chi 2$ - test with Yates correction or Fisher's exact test, when appropriate. Odds ratios (ORs) and $95 \%$ confidence intervals (CIs) were calculated. The following genetic models and test were analyzed: allelic model: D compared with $\mathrm{d}(\mathrm{d}$ - the minor allele); genotypic tests - homozygous model (DD compared with dd), heterozygous model (Dd compared with dd); recessive model (dd compared with Dd + DD); dominant model (dd+Dd compared with DD); over-dominant model (DD+dd compared with Dd); codominant model (DD compared with Dd, compared with dd). A probability value of $P<0.05$ was considered statistically significant.

\section{Results and Discussion}

Among 60 OFC patients, CLP was found in 31(51.7\%) cases, CLO in 14(23.3\%) cases, and CPO in $15(25 \%)$ cases.
As known, the prevalence of OFC varies according to gender and the nature of the cleft. For example, Mossey et al. ${ }^{(13)}$ found a predominance of CLP in men, with a sex ratio (M/F) of $1.81(95 \% \mathrm{CI}: 1.75-1.86)$ and the opposite ratio for CPO 0.93(95\% CI:0.89-0.96); however, one Danish study failed to find a significant predominance of women with cleft palate..$^{(14)}$ In our study, among CLP cases, boys predominated slightly (51.7\%). Analysis of the gender distribution found that CLO was more common in boys (57.2\%) and CPO in girls (66.7\%). Our study is comparable to the results obtained by Tafazzoli and Shahryari. ${ }^{(15)}$

NSCL/P has a multifactorial etiology that includes both genetic and environmental factors, and several genes have been associated with this malformation. ${ }^{(16)}$

More than $40 \%$ of OFC children had a family history of the disease. Since the mechanism of occurrence of each type of cleft is different, we compared the genetic variants of the MDRI rs1045642 SNP and the MTHFR rs1801133 SNP in patients with CLP, CLO, and CPO. Our analysis showed (Table 2) no

Table 2.

Results of allelic and genotype analysis

\begin{tabular}{|c|c|c|c|c|c|c|c|c|c|c|c|c|}
\hline \multirow{2}{*}{ Gene } & \multirow{2}{*}{ Group } & \multirow{2}{*}{$\mathrm{CC}$} & \multirow{2}{*}{$\mathrm{CT}$} & \multirow{2}{*}{ TT } & \multirow{2}{*}{$\mathrm{C}$} & \multirow{2}{*}{$\mathrm{T}$} & \multirow{2}{*}{$\chi^{2}$} & \multirow{2}{*}{$P$-value } & \multicolumn{2}{|c|}{ Genotypes } & \multicolumn{2}{|c|}{ Alleles } \\
\hline & & & & & & & & & HWE & $P$-value & HWE & $P$-value \\
\hline \multirow{15}{*}{$\begin{array}{c}\text { MTHFR } \\
\text { rs1801133 }\end{array}$} & CLP & 69.4 & 30.6 & 0 & 0.847 & 0.153 & 1.171 & 0.279 & & & & \\
\hline & M & 73.7 & 26.3 & 0 & 0.868 & 0.132 & 0.436 & 0.509 & \multirow{2}{*}{ NA } & \multirow{2}{*}{ NA } & \multirow{2}{*}{0.40} & \multirow{2}{*}{0.841} \\
\hline & $\mathrm{F}$ & 64.7 & 35.3 & 0 & 0.824 & 0.176 & 0.781 & 0.377 & & & & \\
\hline & CLO & 50 & 50 & 0 & 0.750 & 0.250 & 0.889 & 0.346 & & & & \\
\hline & M & 50 & 50 & 0 & 0.750 & 0.250 & 0.667 & 0.414 & \multirow{2}{*}{ NA } & \multirow{2}{*}{ NA } & \multirow{2}{*}{0.444} & \multirow{2}{*}{0.505} \\
\hline & $\mathrm{F}$ & 50 & 50 & 0 & 0.750 & 0.250 & 0.222 & 0.637 & & & & \\
\hline & \begin{tabular}{|l|}
$\mathrm{CPO}$ \\
\end{tabular} & 68.8 & 31.3 & 0 & 0.844 & 0.156 & 0.549 & 0.459 & & & & \\
\hline & $M$ & 50 & 50 & 0 & 0.750 & 0.250 & 0.667 & 0.414 & \multirow{2}{*}{ NA } & \multirow{2}{*}{ NA } & \multirow{2}{*}{0.395} & \multirow{2}{*}{0.530} \\
\hline & $\mathrm{F}$ & 80 & 20 & 0 & 0.900 & 0.100 & 0.123 & 0.725 & & & & \\
\hline & \begin{tabular}{|l|} 
NSCL/P \\
\end{tabular} & 66.7 & 33.3 & 0 & 0.833 & 0.167 & 2.400 & 0.121 & & & & \\
\hline & M & 64.5 & 35.5 & 0 & 0.823 & 0.177 & 1.442 & 0.230 & \multirow{2}{*}{ NA } & \multirow{2}{*}{ NA } & 0.07 & 0.035 \\
\hline & $\mathrm{F}$ & 69.0 & 31.0 & 0 & 0.845 & 0.155 & 0.978 & 0.323 & & & 0.07 & 0.953 \\
\hline & \begin{tabular}{|l|} 
Control \\
\end{tabular} & 70.1 & 28.2 & 1.7 & 0.842 & 0.158 & 0.588 & 0.443 & & & & \\
\hline & M & 78.3 & 19.6 & 2.2 & 0.880 & 0.120 & 0.230 & 0.632 & 2306 & 0316 & 1026 & 0311 \\
\hline & $\mathrm{F}$ & 67.2 & 31.3 & 1.6 & 0.828 & 0.172 & 1.224 & 0.269 & 2.500 & 0.010 & 1.020 & 0.511 \\
\hline Gene & Group & $\mathrm{CC}$ & CT & TT & $\mathrm{C}$ & $T$ & & $P$-value & Ger & types & & les \\
\hline Gene & Group & $\mathrm{CC}$ & $\mathrm{Cl}$ & 11 & C & 1 & $x^{2}$ & $P$-value & HWE & $P$-value & HWE & $P$-value \\
\hline & CLP & 11.1 & 63.9 & 25.0 & 0.431 & 0.569 & 3.303 & 0.690 & & & & \\
\hline & M & 5.3 & 68.4 & 26.3 & 0.395 & 0.605 & 3.544 & 0.60 & 1306 & 0408 & 0160 & 0681 \\
\hline & $\mathrm{F}$ & 17.6 & 58.8 & 23.5 & 0.471 & 0.529 & 0.554 & 0.457 & 1.390 & 0.498 & 0.109 & 0.081 \\
\hline & \begin{tabular}{|l|} 
CLO \\
\end{tabular} & 37.5 & 62.5 & 0 & 0.688 & 0.313 & 1.653 & 0.199 & & & & \\
\hline & M & 50 & 50 & 0 & 0.750 & 0.250 & 0.667 & 0.414 & NA & NA & 097 & 0755 \\
\hline & $\mathrm{F}$ & 0 & 100 & 0 & 0.500 & 0.500 & 2.000 & 0.157 & NA & NA & 0.91 & 0.153 \\
\hline & \begin{tabular}{|l|}
$\mathrm{CPO}$ \\
\end{tabular} & 18.8 & 43.8 & 37.5 & 0.406 & 0.594 & 0.139 & 0.710 & & & & \\
\hline $\begin{array}{l}\text { MDR1 } \\
\text { rs } 1045642\end{array}$ & M & 16.7 & 16.7 & 66.7 & 0.250 & 0.750 & 1.852 & 0.174 & 3810 & 0140 & 1045 & 0307 \\
\hline & $\mathrm{F}$ & 20 & 60 & 20 & 0.500 & 0.500 & 0.400 & 0.527 & 5.010 & 0.143 & $1.04 \mathrm{~J}$ & 0.501 \\
\hline & \begin{tabular}{|l|} 
NSCL/P \\
\end{tabular} & 16.7 & 58.3 & 25.0 & 0.458 & 0.542 & 1.834 & 0.176 & & & & \\
\hline & M & 16.1 & 54.8 & 29.0 & 0.435 & 0.565 & 0.412 & 0.521 & 0563 & 0 & 0112 & 0727 \\
\hline & \begin{tabular}{|l|}
$\mathrm{F}$ \\
\end{tabular} & 17.2 & 62.1 & 20.7 & 0.483 & 0.517 & 1.710 & 0.191 & & 0.155 & 0.113 & 0.131 \\
\hline & \begin{tabular}{|l|} 
Control \\
\end{tabular} & 9.7 & 77.1 & 13.1 & 0.483 & 0.517 & 51.917 & 0 & & & & \\
\hline & M & 10.9 & 73.9 & 15.2 & 0.478 & 0.522 & 10.645 & 0.01 & 0344 & 0842 & 0 & 0983 \\
\hline & $\mathrm{F}$ & 9.4 & 78.1 & 12.5 & 0.484 & 0.516 & 40.720 & 0 & & & & \\
\hline
\end{tabular}

$F$, female; $M$, male. $\chi^{2}$ - test with Yates correction 
significant differences in the allele and genotype frequencies between all subgroups. We also did not find differences in the frequency distribution of alleles and genotypes between boys and girls. As a result, we compared these subgroups with the comparison group regardless of gender.
We found no significant association between the carriage of the unfavorable allele T of the MTHFR rs1801133 SNP and OFC in all subgroups (Table 3).

Analysis of the frequency distribution of alleles and genotypes depending on the severity of clefts showed that

Table 3.

Association of the MDR1 (rs1045642) and MTHFR (rs1801133) polymorphisms with the development of NSCL/P, CLP, CLO, CPO

\begin{tabular}{|c|c|c|c|c|}
\hline MTHFR (rs1801133) & & & & \\
\hline NSCL/P and subgroup & NSCLP & CLP & CLO & $\mathrm{CPO}$ \\
\hline MAF / Associated risk alleles & \multicolumn{4}{|c|}{$\mathrm{T}$} \\
\hline Control genotypes & \multicolumn{4}{|c|}{$122 / 49 / 3$} \\
\hline Sample size (case/control) & $60 / 174$ & $36 / 174$ & $8 / 174$ & $16 / 174$ \\
\hline Case genotypes CC/TC/TT & $40 / 20 / 0$ & $25 / 11 / 0$ & $4 / 4 / 0$ & $11 / 5 / 0$ \\
\hline $\begin{array}{l}\text { Allelic model (T vs C) } \\
(95 \% \mathrm{CI}) \\
P \text {-value }\end{array}$ & $\begin{array}{c}\mathrm{OR}=1.06 \\
(0.61-1.86) 0.82\end{array}$ & $\begin{array}{c}\mathrm{OR}=0.96 \\
(0.47-1.94) 0.91\end{array}$ & $\begin{array}{c}\mathrm{OR}=1.78 \\
(0.55-5.71) 0.36\end{array}$ & $\begin{array}{c}\mathrm{OR}=0.99 \\
(0.36-2.67) \\
0.98\end{array}$ \\
\hline $\begin{array}{l}\text { Dominant model }(\mathrm{TC}+\mathrm{TT} \text { vs CC) } \\
(95 \% \mathrm{CI}) \\
P \text {-value }\end{array}$ & $\begin{array}{c}\mathrm{OR}=1.17 \\
(0.63-2.20) \\
0.62\end{array}$ & $\begin{array}{l}\mathrm{OR}=1.03 \\
(0.47-2.25) \\
0.94\end{array}$ & $\begin{array}{c}\mathrm{OR}=2.35 \\
(0.56-9.74) \\
0.25\end{array}$ & $\begin{array}{c}\mathrm{OR}=1.07 \\
(0.35-3.22) \\
0.91\end{array}$ \\
\hline $\begin{array}{l}\text { Reverse heterozygous model (TC vs CC) } \\
(95 \% \text { CI) } \\
P \text {-value }\end{array}$ & $\begin{array}{c}\mathrm{OR}=1.24 \\
(0.66-2.34) \\
0.50\end{array}$ & $\begin{array}{l}\mathrm{OR}=1.10 \\
(0.50-2.40) \\
0.82\end{array}$ & $\begin{array}{c}\mathrm{OR}=2.41 \\
(0.60-10.35) \\
\quad 0.22\end{array}$ & $\begin{array}{c}\mathrm{OR}=1.13 \\
(0.37-3.43) \\
0.83\end{array}$ \\
\hline $\begin{array}{l}\text { Over-dominant model }(\mathrm{TC} \text { vs TT }+\mathrm{CC}) \\
(95 \% \text { CI }) \\
P \text {-value }\end{array}$ & $\begin{array}{c}\mathrm{OR}=1.28 \\
(0.68-2.40) \\
0.45\end{array}$ & $\begin{array}{c}\mathrm{OR}=1.12 \\
(0.51-2.45) \\
0.77\end{array}$ & $\begin{array}{c}\mathrm{OR}=2.55 \\
(0.61-10.60) \\
0.20\end{array}$ & $\begin{array}{c}\mathrm{OR}=1.16 \\
(0.38-3.51) \\
0.79\end{array}$ \\
\hline \multicolumn{5}{|l|}{ MDR1 (rs1045642) } \\
\hline MAF / Associated risk alleles & \multicolumn{4}{|c|}{$\mathrm{T}$} \\
\hline Control genotypes & \multicolumn{4}{|c|}{$17 / 135 / 23$} \\
\hline Sample size (case/control) & $60 / 175$ & $36 / 174$ & $8 / 174$ & $16 / 174$ \\
\hline $\begin{array}{l}\text { Case genotypes } \\
\text { CC/TC/TT }\end{array}$ & $10 / 35 / 15$ & $4 / 23 / 9$ & $3 / 5 / 0$ & $3 / 7 / 6$ \\
\hline $\begin{array}{l}\text { Allelic model }(\mathrm{C} \text { vs } \mathrm{T}) \\
(95 \% \mathrm{CI}) \\
P \text {-value }\end{array}$ & $\begin{array}{c}\mathrm{OR}=1.10 \\
(0.73-1.67) \\
0.64\end{array}$ & $\begin{array}{c}\mathrm{OR}=1.23 \\
(0.74-2.06) \\
0.42\end{array}$ & $\begin{array}{c}\mathrm{OR}=0.42 \\
(0.14-1.25) \\
0.11\end{array}$ & $\begin{array}{c}\mathrm{OR}=1.36 \\
(0.65-2.85) \\
0.40\end{array}$ \\
\hline $\begin{array}{l}\text { Homozygous model (TT vs CC) } \\
(95 \% \text { CI) } \\
P \text {-value }\end{array}$ & $\begin{array}{c}\mathrm{OR}=1.11 \\
(0.40-3.06) \\
0.84\end{array}$ & $\begin{array}{c}\mathrm{OR}=1.66 \\
(0.44-6.31) \\
0.45\end{array}$ & NA & $\begin{array}{c}\mathrm{OR}=1.48 \\
(0.32-6.77) \\
0.61\end{array}$ \\
\hline $\begin{array}{l}\text { Heterozygous model (TT vs TC) } \\
(95 \% \text { CI }) \\
P \text {-value }\end{array}$ & $\begin{array}{l}\mathrm{OR}=2.52 \\
(1.19-5.32) \\
0.02\end{array}$ & $\begin{array}{l}\mathrm{OR}=2.30 \\
(0.94-5.58) \\
0.08\end{array}$ & NA & $\begin{array}{c}\mathrm{OR}=5.03 \\
(1.55-16.32) \\
0.01\end{array}$ \\
\hline $\begin{array}{l}\text { Reverse heterozygous model (TC vs CC) } \\
\text { ( } 95 \% \text { CI }) \\
P \text {-value }\end{array}$ & $\begin{array}{c}\mathrm{OR}=0.44 \\
(0.19-1.05) \\
0.07\end{array}$ & $\begin{array}{c}\mathrm{OR}=0.72 \\
(0.22-2.35) \\
0.60\end{array}$ & $\begin{array}{l}\mathrm{OR}=0.21 \\
(0.05-0.96) \\
0.06\end{array}$ & $\begin{array}{c}\mathrm{OR}=0.29 \\
(0.07-1.24) \\
0.12\end{array}$ \\
\hline $\begin{array}{l}\text { Recessive model (TT vs CC }+ \text { TC) } \\
(95 \% \text { CI }) \\
P \text {-value }\end{array}$ & $\begin{array}{c}\mathrm{OR}=2.20 \\
(1.06-4.57) \\
0.04\end{array}$ & $\begin{array}{c}\mathrm{OR}=2.20 \\
(0.92-5.27) \\
0.09\end{array}$ & NA & $\begin{array}{c}\mathrm{OR}=3.96 \\
(1.32-11.95) \\
0.02\end{array}$ \\
\hline $\begin{array}{l}\text { Dominant model }(\mathrm{TC}+\mathrm{TT} \text { vs } \mathrm{CC}) \\
(95 \% \mathrm{CI}) \\
P \text {-value }\end{array}$ & $\begin{array}{c}\mathrm{OR}=0.54 \\
(0.23-1.25) \\
0.16\end{array}$ & $\begin{array}{c}\mathrm{OR}=1.16 \\
(0.37-3.68) \\
0.80\end{array}$ & $\begin{array}{c}\mathrm{OR}=0.18 \\
(0.04-0.82) \\
0.04\end{array}$ & $\begin{array}{c}\mathrm{OR}=0.47 \\
(0.12-1.80) \\
0.30\end{array}$ \\
\hline $\begin{array}{l}\text { Over-dominant model }(\mathrm{TC} \text { vs } \mathrm{TT}+\mathrm{CC}) \\
(95 \% \mathrm{CI}) \\
P \text {-value }\end{array}$ & $\begin{array}{c}\mathrm{OR}=0.41 \\
(0.22-0.77) \\
0.01\end{array}$ & $\begin{array}{c}\mathrm{OR}=0.52 \\
(0.24-1.13) \\
0.11\end{array}$ & $\begin{array}{c}\mathrm{OR}=0.49 \\
(0.11-2.16) \\
0.36\end{array}$ & $\begin{array}{c}\mathrm{OR}=0.23 \\
(0.08-0.66) \\
0.01\end{array}$ \\
\hline
\end{tabular}

MAF, minor allele frequency 
the carriage of the TT homozygous genotype of the MDR1 rs1045642 SNP was associated with significant risk for the development of NSCL/P $(\mathrm{OR}=2.52,95 \% \mathrm{CI}$ : 1.19-5.32, $P=0.02$ ).

Analysis of the recessive model also found a significant risk of NSCL/P with the TT genotype carriage $(\mathrm{OR}=2.20,95 \% \mathrm{CI}$ : 1.06-4.57, $P=0.04)$.

Analysis of the over-dominant model (TC vs TT $+\mathrm{CC}$ ) showed that the heterozygous TC genotype had a protective effect $(\mathrm{OR}=0.41,95 \% \mathrm{CI}$ : $0.22-0.77, P=0.01)$ on the development of NSCL/P.

Subgroup analysis according to NSCL/P subtypes (CLO, CPO and CLP) showed that the MDR1 rs1045642 SNP was significantly associated with a high risk of CPO in three genetic models (Table 3): heterozygous [(TT vs TC): $\mathrm{OR}=5.03,95 \% \mathrm{CI}: 1.55-16.32, P=0.01]$, recessive [(TT vs $\mathrm{CC}+\mathrm{TC}): \mathrm{OR}=3.96,95 \% \mathrm{CI}: 1.32-11.95, P=0.02]$, and overdominant [(TC vs TT + CC): $\mathrm{OR}=0.23,95 \% \mathrm{CI}: 0.08-0.66$, $P=0.01]$.

\section{Conclusion}

The present case-control study of two SNPs in the MDRland MTHFR genes revealed a statistically significant increased risk for NSCL/P in carriers of the TT genotype of the MDR1 rs1045642 SNP.

\section{Sources of Funding}

The research was carried out within the framework of the project "Physiological and biochemical mechanisms of adaptation of plants, animals, humans to the conditions of the Arctic/Subarctic and the development of biological products based on natural northern raw materials that increase the efficiency of the adaptation process and the level of human health in extreme environmental conditions" (No. 0297-20210025 registration number AAAA-A21-121012190035-9) and the R\&D "Study of the genetic structure and burden of hereditary pathology of populations of the Republic of Sakha (Yakutia)" (No. USU_507512).

\section{Competing Interests}

The authors declare that they have no competing interests.

\section{References}

1. Ushnitskiy ID, Isakov LO, Vinokurov MM, Oskolskiy GI [Dynamic analysis of the frequency and structure of congenital anomalies of the maxillofacial region in Yakutia]. Dentistry. 2015;94(2):37-39. [Article in Russian].

\footnotetext{
*Corresponding author: Nadezhda I. Pavlova, PhD. Yakut Science Center of Complex Medical Problems. Yakutsk, the Republic of Sakha (Yakutia), Russia.E-mail: solnishko_84@inbox.ru
}

2. Ershova OYu, Menshikova EV. [Congenital malformations of the face, congenital clefts of the upper lip and palate in children (guidelines)]. Yekaterinburg, 2016. [In Russian].

3. Uchaeva VS, Vasiliev Yu.A., Gracheva AS, Gulenko OV, Udina IG [Molecular-genetic study of the role of SNP C677T of the MTHFR gene in the development of congenital isolated clefts of the lip and palate]. Kuban Scientific Medical Bulletin. 2018; 25 (5): 104-110. [Article in Russian].

4. Omoumi A, Wang Z, Yeow V, Wu-Chou YH, Chen PK, Ruczinski I, Cheng J, Cheah FS, Lee CG, Beaty TH, Chong $\mathrm{SS}$. Fetal polymorphisms at the ABCB1-transporter gene locus are associated with susceptibility to non-syndromic oral cleft malformations. Eur J Hum Genet. 2013 Dec;21(12):1436-41. doi: 10.1038/ejhg.2013.25.

5. Wang Y, Zheng G, Kang M, Tang W, Cai W, Huang Z. Methylenetetrahydrofolate reductase rs1801133 C>T polymorphism is association with nonsyndromic cleft lip with or without cleft palate susceptibility: A meta-analysis. International Journal of Clinical and Experimental Medicine. 2017;10 (2):1734-1749

6. Crider KS, Bailey LB, Berry RJ. Folic acid food fortification-its history, effect, concerns, and future directions. Nutrients. 2011 Mar;3(3):370-84. doi: 10.3390/nu3030370.

7. Jägerstad M. Folic acid fortification prevents neural tube defects and may also reduce cancer risks. Acta Paediatr. 2012 Oct;101(10):1007-12. doi: 10.1111/j.16512227.2012.02781.x.

8. Chang $\mathrm{H}$, Zhang $\mathrm{T}$, Zhang $\mathrm{Z}$, Bao R, Fu C, Wang Z, Bao Y, Li Y, Wu L, Zheng X, Wu J. Tissue-specific distribution of aberrant DNA methylation associated with maternal low-folate status in human neural tube defects. J Nutr Biochem. 2011 Dec;22(12):1172-7. doi: 10.1016/j. jnutbio.2010.10.003.

9. Lowensohn RI, Stadler DD, Naze C. Current Concepts of Maternal Nutrition. Obstet Gynecol Surv. 2016 Aug;71(7):41326. doi: 10.1097/OGX.0000000000000329.

10. Czeizel AE, Dudás I, Paput L, Bánhidy F. Prevention of neural-tube defects with periconceptional folic acid, methylfolate, or multivitamins? Ann Nutr Metab. 2011 Oct;58(4):263-71. doi: 10.1159/000330776.

11. Bailey LB, Berry RJ. Folic acid supplementation and the occurrence of congenital heart defects, orofacial clefts, multiple births, and miscarriage. Am J Clin Nutr. 2005 May;81(5):1213S-1217S. doi: 10.1093/ajcn/81.5.1213.

12. Pel's IaR, Marusin AV, Spiridonova MG, Stepanov VA. [Polymorphism of human MDR1 gene in the Siberian and central Asian populations]. Mol Biol (Mosk). 2007 NovDec;41(6):982-8. [Article in Russian].

13. Mossey PA, Castilla EE. Global Registry and Database on Craniofacial Anomalies: Report of a WHO Registry Meeting on Craniofacial Anomalies. Geneva, Switzerland: World Health Organization; 2001.

14. Christensen K, Holm NV, Olsen J, Kock K, FoghAndersen P. Selection bias in genetic-epidemiological studies of cleft lip and palate. Am J Hum Genet. 1992 Sep;51(3):6549 .

15. Tafazzoli H, Shahryari A. Prevalence of cleft lip and palat in Qazvin and its etiology in patients referring to Dental University. J Qazvin Univ Med Sci. 2001;5:76-80.

16. Mangold E, Ludwig KU, Nöthen MM. Breakthroughs in the genetics of orofacial clefting. Trends Mol Med. 2011 Dec;17(12):725-33. doi: 10.1016/j.molmed.2011.07.007. 